\title{
Introduction: Security/Mobility and the politics of movement
}

\author{
Marie Beauchamps, Marijn Hoijtink, Matthias Leese, Bruno \\ Magalhães, Sharon Weinblum, and Stef Wittendorp
}

$\mathrm{M}$ OBILTY TODAY IS regarded as both a condition of global modernity and as a source of insecurity. Not only are people on the move every day and on an unprecedented scale, but also a multiplicity of non-humans move and are being moved. Indeed, 'from SARS and avian influenza to train crashes, from airport expansion controversies to controlling global warming, from urban congestion charging to networked global terrorism, from emergency management in the onslaught of tsunamis and hurricanes to oil wars in the Middle East' (Hannam et al. 2006: 1), a diverse range of concrete and abstract things have become highly global and mobile. While such movement is often considered part and parcel of modernity, it also brings about increased complexity that becomes enmeshed with conceptualisations of threat - it is discourses about organized crime, global terrorism, undocumented migration and other dangerous mobilities' (Walters 2006: 199) that render movement a central political concern.

While contemporary liberal politics actively encourages and enables mobility for the sake of our modern lifestyle and the economic benefits that it yields, it also seeks to render the flows of such mobility knowledgeable and controllable. In order to do so, borders undergo restructuring and reorganisation into flexible filters that rely on accumulated knowledge about passers-through; data on travellers and goods now easily supersedes the speed of physical bodies and subsequently can be analysed and acted upon long before the arrival of an actual aircraft or sea vessel; and new technologies such as radio frequency identification (RFID) tags and GPS satellites make it possible to track and survey the movement of humans and objects across space in real time. This list of examples is tentative and could easily be continued - yet it is emblematic of a way of thinking about security and mobility together that is reflected in political programmes and ensuing analyses. What is striking is that research from the field of critical security studies largely focuses on movement as such, and on how it becomes targeted, regulated, and intervened upon. The emphasis, in accordance with the 
political programmes that are meant to produce security, is predominantly on things and people on the move.

Less attention has been paid so far to the underlying physical infrastructures of such movement. The tangible, material side of mobility - the roads and tracks; the cars, boats, and planes; the architecture and barriers - has in fact long been taken for granted (Walters 2015). However, more recently, critical geographers have started to engage this seemingly immobile side of mobility - the 'fixities' and 'moorings' (Urry 2003: 138) that provide the often unspectacular and yet crucial underpinnings of movement. They call for emphasis to be placed on the enabling or restraining effects of what could be subsumed as mobility infrastructures. This book takes inspiration from this. In the vein of what has been deemed a 'new mobilities paradigm' (Sheller and Urry 2006), we seek to bring together two closely related strands of research: (1) inquiries that look into the political regulation of movement; and (2) analyses that engage the material enablers and constraints of such movement. We thereby attempt to bridge theoretical perspectives from critical security studies and political geography in order to provide a more comprehensive perspective on security and mobility.

To be concise: there are no clear-cut boundaries to be found between those two strands of research, and scholars have already started to transcend the permeable membranes between different layers of movement, as is detailed below. And yet we feel that intensified dialogue between mobilities and immobilities can in fact yield additional benefits for a critical problematisation of movement. This book is an attempt to gather perspectives on mobility that take into account both techniques and practices of regulating movement, as well as their underlying infrastructures. Together they form a perspective on a politics of movement that lies at the core of the production of security. Drawing on the insight that security is a contingent concept that hinges on the social construction of threat - which in turn must be understood through its political, social, economic, and cultural dimensions - we seek to contribute to a more fine-grained perspective on a presumably mobile and insecure world. The title of this book, Security/Mobility, is a direct reference to this world that at times appears dominated by these two paradigms. They are not opposed to each other, and, as hinted at above, a great deal of political effort is undertaken in order to reconcile the need for security and the necessity of mobility. We might say that security and mobility are entangled in a constant dynamic - a dynamic that converges in what we have conceptualised here as a politics of movement.

Before engaging the empirical contributions to this book, this introductory chapter looks a little closer into both the critical security studies literatures on mobility and into the 'new mobilities' literature, thereby providing broader conceptual ground for the analyses that follow. At the same time, it serves as an exploration of the potential pitfalls that can emerge through thinking about security and mobility together. In fact, as Peter Adey (2006b) 
reminds us, 'if mobility is everything then it is nothing' - an overstretching of mobility as the key characteristic of modernity would indeed produce an empty signifier that loses its analytical purchase. This is not the only caveat. Debates on security, especially in the vein of securitisation theory, have witnessed similar arguments: if everything can be turned into a security matter, then security ends up being a hollow concept (Huysmans 1998). And yet, the world around us appears to be more mobile and more insecure than ever - or at least so political arguments go. Methodologically, we must be careful not to fall into the trap of overgeneralisation, thereby producing generic statements devoid of meaning. The contributions to this book avoid those pitfalls by engaging very specific sites of security/mobility, en route contextualising and carefully fleshing out the concepts with empirical detail. Not only do they provide fine-grained inquiries, but they also reconnect such inquiries to the overarching thematic of this book. They do so by thinking about power and government, about materiality and discourse, about identity and the law - in short: by thinking about the politics of movement.

\section{Security}

The meaning of security is hard to pin down. When talking about security, one must first clarify a number of questions: "what or who is to be secured from what or whom?', 'who should do security?', 'on what political and normative grounds should it be done?', 'how should it be done and what means should be used?', and so on. The answers to such questions are not easy. Depending on the perspective, we might say that security is either a necessary condition for any society (e.g., Der Derian 1995; Burgess 2011), a pathological tendency that potentially undermines what it was set to protect (e.g., Neocleous 2008; Molotch 2012), a means of government (e.g., Foucault 2007; 2008) - or all of these at the same time. In this regard, once more, there is not much difference between the concepts of security and mobility. Both remain abstract until they are filled with concrete, empirical meaning. The mobility part of Security/Mobility must relate, as we detail below, to questions of who or what moves, to the speeds and rhythms of movement, to origins, destinations, and directions, to means and methods of movement, and many more. But let us first look at how critical security studies have engaged mobility.

If we were to pick one major theme, it would probably be that a main characteristic of the current politics of security is that it thrives on the openness of our times. Drawing on the work of Michel Foucault (2007; 2008) who argued that mobility (he uses the term circulation to be more precise) has become a prime target for political intervention at the threshold of modernity, scholars have analysed the political attempts to know, analyse, and subsequently sort 
flows of mobility according to ascribed levels of threat. This literature, as it follows the political narratives of 'dangerous mobilities' (Walters 2006: 199), has been primarily concerned with themes that emerge around migration and the war on terror. Two unrelated figures of mobility have become connected in political discourses concerned with both security and mobility: on the one side of the spectrum, the figure of the migrant, which relates to (mass) movement itself, and whose arrival, often at the cost of the migrant's own safety, has become somewhat emblematic of political discourses on security. On the other side of the spectrum, the figure of the terrorist represents the ultimate threat that is perceived to be endangering society; the figure of the terrorist relates to movement as its suspicious presence is identified and filtered as a dangerous element within the flows of global movement in order to render us more secure and prevent the next attack.

As a result, the institutions, techniques, and technologies that monitor and regulate global flows have commanded reinforced academic attention. This is evident from inquiries into a broad range of topics: the discursive and practical regimes that attempt to sketch out the presumable danger from unrestricted movement (e.g., Jackson 2005; Balzacq 2011; Bigo 2002; Huysmans 2006; 2011); the transformation of borders and border checkpoints in the struggle against (illegal) movement (e.g., Salter 2004; Walters 2006; Pallitto and Heyman 2008; Muller 2009; Parizot et al. 2014); airports and their security regimes as the most symbolic sites of the fight against global terror after 9/11 (e.g., Salter 2008; Adey 2004; Leese and Koenigseder 2015; Lyon 2006; Schouten 2014); the practice of information-gathering, databases, and algorithms that inform risk assessments and other forms of anticipation (e.g., Amoore and De Goede 2008; Lyon 2003; Gandy 2010; De Vries 2010; Amoore 2011; Rouvroy 2013; Leese 2014); or the modes of cooperation and information exchange between security agencies and security professionals (e.g., Bigo et al. 2007; Balzacq 2008; Geyer 2008; De Hert and Bellanova 2011). This is another list that could be continued, but it suffices to illustrate the wide array of inquiries into mobility against the backdrop of the politics of security.

Before briefly turning to mobility in the next section, it should be pointed out that there have been valuable attempts to draw attention to some of the seemingly immobile infrastructures of security (politics). Notably, scholars have engaged architecture (e.g., Adey 2008; Fuller 2008; Jones 2009), and fences and walls that physically direct, interrupt, or constrain movement (e.g., Latte Abdallah and Parizot 2010; Vallet and David 2012; Rosière and Jones 2012; Pallister-Wilkins 2011; 2015), thereby highlighting the importance of materialities in the political regulation of movement and speaking directly to the analytical agenda that the 'new mobilities' literature has laid out. 


\section{Introduction}

\section{Mobility}

It is precisely the political regulation of movement that the 'new mobilities' literature takes as its point of departure. In this vein, it reacts against work that takes human movement for granted. As observed by Tim Cresswell (2010: 18, emph. in orig.), earlier work on mobility was 'rarely actually about mobility'. Subsequently, more recent work on mobility problematises how mobility is brought into being, while at the same time scrutinising how (new) forms of mobility (re)structure social life (e.g., Cresswell 2006; 2010; Sheller and Urry 2006; Adey 2010). According to Jørgen Ole Bærenholdt (2013: 20-1) 'mobility studies draw an image of societies as being made up of various mobility systems as well as new forms of social obligations performed through these systems which ensure both connections at a distance and face-to-face meetings of otherwise detached persons'. The reinforced emphasis on mobility has spawned a cross-disciplinary research agenda that engages the rapidly changing social, political, and economic dynamics produced through mobility, and which are simultaneously productive of specific forms of mobility. There is a thriving body of literature that analyses expressions of mobility in areas such as globalised regimes of travel and transportation, leisure and business, borders and migration, communication and digitisation (e.g., Shamir 2005; Hannam et al. 2006; Sheller and Urry 2006; Urry 2007; Adey 2010; Squire 2011a; Bærenholdt 2013; Salter 2013).

Mobility must not, so goes the thrust of the argument, be conceived of in a singular fashion, but in a pluralistic, mutually constitutive sense that produces complex and layered assemblages of movement. Mobility is defined by Cresswell (2006: 3) as 'socially produced motion' in order to distinguish it from movement that denotes 'the general fact of displacement'. The concept of mobility thereby attunes the analyst to consider the strategies and social implications of bringing about movement (Cresswell 2006: 3). Adey (2010: 18) argues that mobility is necessarily relational, as every mobility is entangled with other mobilities. The linking of multiple mobilities can in fact generate 'zones of connectivity, centrality, and empowerment' (Sheller and Urry 2006: 210). Such constellations of mobilities can appear at first glance as immobile structures due to their seamless functioning whereby interacting parts appear as a whole (Adey 2010: 26). Mobility studies thus train the eye of the observer not to take for granted the conditions that make the movement of subjects and objects possible and thereby look anew at what appears initially as fixed or immobile.

However, mobility studies are not a plea to get rid of the category of fixity. To the contrary, as John Urry (2003: 138) points out, certain immobilities, also referred to as 'fixities' or 'moorings', in fact enable movement. Airports serve as a prime example of how mobility and immobility stand in a co-constitutive relation (e.g., Adey 2006a; 2008; Sheller and Urry 2006: 210). The highly mobile 
business person, the tourist, the migrant, the criminal, and the terrorist - their movement is made possible by vastly immobile structures such as runways, arrival and departure terminals, and entry and exit routes to connecting cities (cf. Adey 2006b). Approaching mobility as sets of differentiated relations draws attention to how forms of mobility and immobility are produced in an overlapping and productive manner rather than as a dichotomy between the mobile and the immobile (Sheller and Urry 2006: 216). By viewing social relations from the perspective of mobility, the supposedly immobile is revealed as having a 'hidden ... history of trajectories of movement and social relations' (Adey 2010: 26). The mobile and immobile are infused with a politics that needs to be brought into the open.

\section{Towards a politics of movement}

Mobility is never innocent. Gains in mobility to some simultaneously produce 'disconnection, social exclusion, and inaudibility' for others (Sheller and Urry 2006: 210). As Cresswell (2010: 20-1) puts it, 'forms of mobility ... are political - they are implicated in the production of power and relations of domination', which means that 'speeds, slownesses, and immobilities are all related in ways that are thoroughly infused with power and its distribution'. Consider, for instance, the practices at border checkpoints and airports: depending on factors such as citizenship, job status, travel history, membership of a frequent flyer club, or even a trusted traveller status that usually includes some form of security clearance, people will be treated in ways that are highly contingent on imaginaries of threat. As Robert Pallitto and Josiah Heyman (2008: 319) observe, 'security technologies frequently involve risk classification: who is to be inspected more closely or thoroughly, or who is to be permitted freer/faster movement'. Movement entails varying velocities, often justified by security arguments, and just as often grounded in the willingness to pay, as 'fast-tracking and convenience slowly trump all other concerns' (Muller 2010: 84). Each trajectory of movement comes with its own starting point, speed, rhythm, routing, experience, and friction (Cresswell 2010: 22) that, when taken together, constitute a complex, heterogeneous set of power relations.

Security and mobility, this much should have become apparent throughout this brief introduction, are politically charged concepts. This book seeks to highlight and scrutinise the politics of movement - manifesting itself in questions of who can be mobile, in what ways, when, and under what conditions - and the sites where those politics materialise and unfold their effects. The political regulation of movement hinges to a large extent on ongoing political struggles about who or what constitutes desirable or undesirable movement (Bigo 2002; Squire 2011b). This relates, amongst others, to the diverging experiences of people on the move - of tourists, business persons, commuters, students, asylum seekers, 
and migrants. Equally, it relates to the role played by politicians, bureaucrats, border guards, and also less visible but no less important administrators, their managers, and software engineers designing algorithms for risk assessment technology.

It would be a mistake to regard the intertwining of security and mobility as a centralised, large-scale operation. On the contrary, as Mimi Sheller and John Urry (2006: 214) write, 'there are hybrid systems, "materialities and mobilities", that combine objects, technologies, and socialities, and out of those distinct places are produced and reproduced'. Interconnected trajectories of movement should then be seen as 'complex systems that are neither perfectly ordered nor anarchic' but display an 'orderly disorder' (Sheller and Urry 2006, 216). Security/Mobility is not a stable relationship, but a dynamic one that emerges and re-emerges across different spatial and temporal arrangements. Mobility, as Cresswell (2010: 18) tells us, 'involves a fragile entanglement of physical movement, representations, and practices'. It is exactly those movements, representations, and practices, infused with and the product of discourses about security, that are subjected to empirical scrutiny and theoretical reflection in this book. By approaching the production of security through the lens of mobility we encourage new questions, engage established themes anew and explore new empirical sites.

\section{Book outline}

This book is divided into three main parts, which are framed by a prologue and an epilogue. The main parts are organised around the movement of things (Part I), the movement of people (Part II), and circumscribing movement (Part III). The authors engage a wide range of topics, concepts, and empirical sites. By highlighting mobility and immobility related to a red thread of (in)security, they flesh out what contemporary politics of movement look like. As argued above, a conceptually broad inquiry into security and mobility could lead to the suggestion of nearly all empirical findings being easily related to either security or mobility. The contributions to this book circumvent such a trap through their common reflection on the politics of movement. The chapters speak directly to questions of who/what moves, to the conditions and shapes of movement, and to the overarching frameworks of security politics that enable or constrain movement.

In the prologue (Chapter 2), Luis Lobo-Guerrero and Friederike Kuntz provide a contextualisation of the book's theme through the juxtaposition of contemporary and historical travel. Their chapter explores the notion of connectivity as making possible forms of security and mobility in different historical periods. Starting from a reflection on present-day liberal forms of mobility and security that rely on the active circulation of various elements, 
the mainstay of the chapter is an exploration of a sixteenth-century Christian travel account mapping the biblical world and the kind of connectivity regarding mobility and security inscribed by this account. Their work unsettles today's taken-for-granted notion of effortless mobility and connectivity through the descriptions of dangerous travels in the sixteenth century, thus providing a change of perspective that highlights the contingency of contemporary mobility and security.

The first thematic block of the book is dedicated to inquiries of how things move. Andreas Baur-Ahrens (Chapter 3) engages the (re)organisation of cyberspace by examining the ongoing debates on data territorialisation. Building on cybersecurity discourses after the Snowden revelations, he analyses how the movement of data is supposed to be constrained such that it literally would not leave the territory of a nation state on its way from sender to receiver. BaurAhrens thereby highlights - against the placeless notion of cyberspace - the importance of the physical infrastructures of servers and data exchange points that exist in concrete buildings on national territories. The argument behind the rerouting initiatives he looks into is that data, once it does not physically leave the country on its travels, would be easier to protect. However, as Baur-Ahrens argues, such a political intervention into the open architecture of the Internet entails deep-seated transformations of power in cyberspace.

Pointing to a more abstract notion of security and mobility, Erella Grassiani (Chapter 4) demonstrates how knowledge about security becomes a commodity that can be marketed, sold, and, in fact, moved. Engaging the reputation of the Israeli Defence Forces as not only experts in security, but notably practitioners of security, Grassiani shows how private security firms in the United States construct their business model around precisely this reputation. She highlights the capacities of markets to render things mobile and relocate the abstract notion of Israeli security to another country where it manifests itself and transcends boundaries from the military sector to private service provisions for the civil sector. These companies do so by transforming their 'Israeli Security Experience' into a brand that symbolises not only security and safety but also values such as discretion and toughness.

In the last chapter of the first part of the book, Nathaniel O'Grady (Chapter 5) takes us on a journey - one that is as concrete as it is transformative. In his analysis of the British Fire and Rescue Services, he traces how data travels through their digital infrastructures until it is finally computed into risk assessments that intend to predict future occurrences of fire and thereby serve as a means of government. O'Grady points to the contingent nature of data, and how it changes both form and content as it becomes mobilised from one department to another. Similarly to Baur-Ahrens, the emphasis is on the mobile as well as the immobile parts of this journey at the end of which stands a novel technique of intervention into one of the most ancient and yet current threats, that of fire. 


\section{Introduction}

The second part of the book engages the movement of people. It is probably the most traditional part, as its contributions examine discourses of migration and asylum, and, closely connected to this, the mobilising, organising, and restructuring of borders. Through their methodological choice for discourse, the chapters manage to sketch out how both mobility and security are made meaningful and how the dynamics between who or what is considered dangerous and who or what can be mobile and under what conditions have an impact on what is understood as security as well as mobility. In the first contribution, Giannis Gkolfinopoulos (Chapter 6) looks at the hunger strike of migrants in the Law School building of the University of Athens in 2011. He focuses on the media representations of the occupation of the building and the discursive construction of threats around the hunger strike. Notably, the construction of threat images turns out to be closely related to the university and the Law School building - both as an institution and as a concrete building - the prestige of which was presented to be endangered.

Similar themes, although concerning a different case study, are picked up by Sharon Weinblum (Chapter 7). She engages the Israeli border discourse against the backdrop of arriving asylum seekers from Africa. Focusing on parliamentary debates, the chapter looks at how exclusionary techniques employed to regulate migrations are legitimised through the association of migrants as a problem of national security, as an economic threat, and as a threat to national identity. Contrary to the literature that examines borders as dislocated sites of control, the chapter instead directs attention to the regulation of migrations through very classical discursive frameworks: as tools of ordering, controlling, and physical enactment of statecraft and sovereignty.

Stef Wittendorp (Chapter 8) examines from a discourse perspective the debate on the abolition of border controls in the European Community (EC) in the second half of the 1980s. The chapter examines how the shifting constellation between the border as security device and as economic enabler made possible the removal of border controls as well as conceiving new forms of regulating security and mobility. In a broader context, the chapter is critical of the view of the EC and now European Union as a post-national entity that has successfully moved beyond a divisionary and exclusive nationally oriented politics. Instead, the regulation of mobility and thus the politics of inclusion and exclusion continue apace, although perhaps in less visible and more unexpected places.

Whereas the second part of the book addresses the movement of people as such and its public and political representation, the last part is dedicated to analyses of how movement is (actively) circumscribed. Christine Quinan (Chapter 9) starts this part by addressing questions of neoliberalism and gender surveillance in a post-9/11 era. The chapter discusses the boundaries of citizenship in a system that actively attempts to exclude, alienate, and violate certain identities, particularly transgender individuals and racialised or religious 'others'. 
Bruno Magalhães (Chapter 10) examines the practices of judging the credibility of asylum requests in Brazil. Through ethnographic research with various Brazilian agencies involved in the asylum procedure, the chapter is concerned with how asylum cases come to be regarded as consistent or not; consistency being a requirement for granting asylum. Annemarie Mol's work on ontological coordination is drawn on to understand how different enactments of an asylum case are arranged. As such, the chapter is critical of procedures based on checklists since these overviews encourage a singular view of an asylum case in which there is little room for unexpected and genuine new information that might challenge the established view of the case.

The final chapter of the last part looks at the active expulsion of citizens from their national territory. Adding a historical note to a practice that has recently garnered renewed attention, Marie Beauchamps (Chapter 11) looks at the policy of denaturalisation in France at the beginning of World War II. Denaturalisation law as a juridical political discourse centres on the deprivation of citizenship; it draws on security rhetoric in order to rewrite the limits of inclusion and exclusion regarding citizenship and is a means to model the national community. Based on archival material collected at the French National Archives, she argues that denaturalisation law is at the core of the security/mobility dynamic: emphasising a fear of movement on the one hand, and the operationalisation of adaptable juridical practices on the other hand, denaturalisation interrupts our capacity for dissent while fixing the means to govern beyond democratic control. Her analysis thereby contributes to a better understanding of the politics of nationality where notions of selfhood and otherness are being shaped, mobilised, and transformed.

The book is capped off by a short epilogue. While the prologue serves to contextualise historically and unsettle contemporary notions of security and mobility, the epilogue makes an effort to close the bracket that this introduction has opened. Arguing from the disciplinary perspective of critical security studies, Emmanuel-Pierre Guittet (Chapter 12) takes a step back and evaluates what lessons can be learned from an agenda of Security/Mobility.

\section{REFERENCES}

Adey, P., 2004. 'Secured and Sorted Mobilities: Examples from the Airport', Surveillance E Society 1(4): 500-19.

Adey, P., 2006a. “"Divided we Move”: The Dromologics of Airport Security and Surveillance', in T. Monahan, ed., Surveillance and Security. Technological Politics and Power in Everyday Life, New York/London: Routledge.

Adey, P., 2006b. 'If Mobility is Everything Then it is Nothing: Towards a Relational Politics of (Im)mobilities', Mobilities 1(1): 75-94.

Adey, P., 2008. 'Airports, Mobility and the Calculative Architecture of Affective Control', Geoforum 39(1): 438-51. 


\section{Introduction}

Adey, P., 2010. Mobility, Milton Park/New York: Routledge.

Amoore, L., 2011. 'Data Derivatives: On the Emergence of a Security Risk Calculus for Our Times', Theory, Culture \& Society 28(6): 24-43.

Amoore, L. and M. De Goede, eds, 2008. Risk and the War on Terror, London/ New York: Routledge.

Bærenholdt, J. O., 2013. 'Governmobility: The Powers of Mobility', Mobilities 8(1): 20-34.

Balzacq, T., 2008. 'The Policy Tools of Securitization: Information Exchange, EU Foreign and Interior Policies', Journal of Common Market Studies 46(1): 75-100.

Balzacq, T., ed., 2011. Securitization Theory: How Security Problems Emerge and Dissolve, Milton Park/New York: Routledge.

Bigo, D., 2002. 'Security and Immigration: Toward a Critique of the Governmentality of Unease', Alternatives: Global, Local, Political 27(1): 63-92.

Bigo, D., L. Bonelli, D. Chi, and C. Olsson, 2007. 'Mapping the Field of the EU Internal Security Agencies', in D. Bigo, ed., The Field of the EU Internal Security Agencies, Paris: L'Harmattan.

Burgess, J. P., 2011. The Ethical Subject of Security: Geopolitical Reason and the Threat Against Europe, Milton Park/New York: Routledge.

Cresswell, T., 2006. On the Move: Mobility in the Modern Western World, Milton Park/ New York: Routledge.

Cresswell, T., 2010. 'Towards a Politics of Mobility', Environment and Planning D: Society and Space 28(1): 17-31.

De Hert, P. and R. Bellanova, 2011. Transatlantic Cooperation on Travelers' Data Processing: From Sorting Countries to Sorting Individuals, Washington, DC: Migration Policy Institute.

De Vries, K., 2010. 'Identity, Profiling Algorithms and a World of Ambient Intelligence', Ethics and Information Technology 12(1): 71-85.

Der Derian, J., 1995. 'The Value of Security: Hobbes, Marx, Nietzsche, and Baudrillard', in R. D. Lipschutz, ed., On Security, New York/Chichester: Columbia University Press.

Foucault, M., 2007. Security, Territory, Population. Lectures at the Collège de France, 1977-78, New York: Palgrave Macmillan.

Foucault, M., 2008. The Birth of Biopolitics. Lectures at the Collège de France 1978-79, New York: Palgrave Macmillan.

Fuller, G., 2008. 'Welcome to Windows 2.1: Motion Aesthetics at the Airport', in M. B. Salter, ed., Politics at the Airport, Minneapolis, MN/London: University of Minnesota Press.

Gandy, O. H., 2010. 'Engaging Rational Discrimination: Exploring Reasons for Placing Regulatory Constraints on Decision Support Systems', Ethics and Information Technology 12(1): 29-42.

Geyer, F., 2008. Taking Stock: Databases and Systems of Information Exchange in the Area of Freedom, Security and Justice. Challenge Research Paper No. 9 Available at www. libertysecurity.org/IMG/pdf_Databases_and_Systems_of_Information_Exchange_ in_the_Area_of_Freedom_Security_and_Justice.pdf (accessed 7 July 2014).

Hannam, K., M. Sheller, and J. Urry, 2006. 'Editorial: Mobilities, Immobilities and Moorings', Mobilities 1(1): 1-22. 
Huysmans, J., 1998. 'Security! What Do You Mean? From Concept to Thick Signifier', European Journal of International Relations 4(2): 226-55.

Huysmans, J., 2006. The Politics of Insecurity. Fear, Migration and Asylum in the EU, Milton Park/New York: Routledge.

Huysmans, J., 2011. 'What's in an Act? On Security Speech Acts and Little Security Nothings', Security Dialogue 42(4-5): 371-83.

Jackson, R., 2005. Writing the War on Terrorism: Language, Politics and Counter-Terrorism, Manchester/New York: Manchester University Press.

Jones, R., 2009. 'Checkpoint Security. Gateways, Airports and the Architecture of Security', in K. F. Aas, H. O. Gundhus and H. M. Lomell, eds, Technologies of InSecurity. The Surveillance of Everyday Life, London: Routledge-Cavendish.

Latte Abdallah, S. and C. Parizot, 2010. A l'ombre du Mur: Israéliens et Palestiniens entre séparation et occupation, Paris: Actes Sud.

Leese, M., 2014. 'The New Profiling: Algorithms, Black Boxes, and the Failure of Anti-discriminatory Safeguards in the European Union', Security Dialogue 45(5): 494-511.

Leese, M. and A. Koenigseder, 2015. 'Humor at the Airport? Visualization, Exposure, and Laughter in the "War on Terror", International Political Sociology 9(1): 37-52.

Lyon, D., ed., 2003. Surveillance as Social Sorting: Privacy, Risk, and Digital Discrimination, London/New York: Routledge.

Lyon, D., 2006. 'Airport Screening, Surveillance, and Social Sorting: Canadian Responses to 9/11 in Context', Canadian Journal of Criminology and Criminal Justice 48(3): 397-411.

Molotch, H., 2012. Against Security: How We Go Wrong at Airports, Subways, and other Sites of Ambigious Danger, Princeton, NJ/Oxford: Princeton University Press.

Muller, B. J., 2009. 'Borders, Risks, Exclusions', Studies in Social Justice 3(1): 67-78.

Muller, B. J., 2010. 'Unsafe at any Speed? Borders, Mobility and "Safe Citizenship", Citizenship Studies 14(1): 75-88.

Neocleous, M., 2008. Critique of Security, Edinburgh: Edinburgh University Press.

Pallister-Wilkins, P., 2011. 'The Separation Wall: A Symbol of Power and a Site of Resistance?', Antipode 43(5): 1851-82.

Pallister-Wilkins, P., 2015. 'Bridging the Divide: Middle Eastern Walls and Fences and the Spatial Governance of Problem Populations', Geopolitics 20(2): 438-59.

Pallitto, R. M. and J. Heyman, 2008. 'Theorizing Cross-Border Mobility: Surveillance, Security and Identity', Surveillance \& Society 5(3): 315-33.

Parizot, C., A. L. A. Szary, G. Popescu, I. Arvers, T. Cantens, J. Cristofol, N. Mai, J. Moll and A. Vion, 2014. 'The antiAtlas of Borders: A Manifesto', Journal of Borderlands Studies 29(4): 503-12.

Rosière, S. and R. Jones, 2012. 'Teichopolitics: Re-considering Globalisation Through the Role of Walls and Fences', Geopolitics 17(1): 217-34.

Rouvroy, A., 2013. 'The End(s) of Critique: Data-behaviourism vs. Due-process', in M. Hildebrandt and K. de Vries, eds, Privacy, Due Process and the Computational Turn. The Philosophy of Law Meets the Philosophy of Technology, Milton Park/ New York: Routledge. 


\section{Introduction}

Salter, M. B., 2004. 'Passports, Mobility, and Security: How Smart Can the Border Be?', International Studies Perspectives 5(1): 71-91.

Salter, M. B., ed., 2008. Politics at the Airport, Minneapolis, MN/London: University of Minnesota Press.

Salter, M. B., 2013. 'To Make Move and Let Stop: Mobility and the Assemblage of Circulation', Mobilities 8(1): 7-19.

Schouten, P., 2014. 'Security as Controversy: Reassembling Security at Amsterdam Airport', Security Dialogue 45(1): 23-42.

Shamir, R., 2005. 'Without Borders? Notes on Globalization as a Mobility Regime', Sociological Theory 23(2): 197-217.

Sheller, M. and J. Urry, 2006. 'The New Mobilities Paradigm', Environment and Planning A 38(2): 207-26.

Squire, V., ed., 2011a. The Contested Politics of Mobility: Borderzones and Irregularity, Milton Park/New York: Routledge.

Squire, V., 2011b. 'The Contested Politics of Mobility: Politicizing Mobility, Mobilizing Politics', in V. Squire, ed., The Contested Politics of Mobility: Borderzones and Irregularity, Milton Park/New York: Routledge.

Urry, J., 2003. Global Complexity, Cambridge: Polity.

Urry, J., 2007. Mobilities, Cambridge: Polity.

Vallet, É. and C.-P. David, 2012. 'Introduction: The (Re)Building of the Wall in International Relations', Journal of Borderlands Studies 27(2): 111-19.

Walters, W., 2006. 'Border/Control', European Journal of Social Theory 9(2): 187-203.

Walters, W., 2015. 'Migration, Vehicles, and Politics: Three Theses on Viapolitics', European Journal of Social Theory 18(4): 469-88. 
Marie Beauchamps, Marijn Hoijtink, Matthias Leese, Bruno Magalhães, and Sharon Weinblum - 9781526108364 Downloaded from manchesterhive.com at 04/26/2023 12:42:59PM 